\title{
AUTOMATIKUS SZERSZÁM- ÉS MEGFOGÓCSERÉLÔ FEJLESZTÉSE IPARI ROBOTOKHOZ
}

\author{
Mihálcz István
}

\section{Összefoglalás:}

Szerelôrobotoknál a mûveletek gyors elvégzéséhez gyakran kell a megfogókat vagy a szerszámokat cserélni. A cserélendô eszközöket automatikusan kell mûködtetni és ezektôl információkat kell átvenni. A cserélôn keresztủl meg kell valósítani az energia és adatok áramlását a robotvezérlô és a cserélô között. Egy ilyen univerzális cserélô nagyon költséges, ezért álltam neki egy ilyen eszköz fejlesztésének. A dolgozat ismerteti a tervezési szempontokat, a cserélô mûködési elvét és a rendszer számítógépes dinamikai analizisét. A cserélô 4 pneumatikus-, 9 ljel- és 2 elektromos teljesítménycsatornát tartalmaz, lehetöség van pneumatikus és elektromos szerszámok mûködtetésére és vezérlésére. A cserélô úgy van kialakítva, hogy egyaránt mûködtethetô elektromos és pneumatikus úton. A nyitásizárási mûveletek optoelektronikus szenzorral vannak felügyelve.

\section{Bevezetés:}

Gyakran elôfordul hegesztô, szerelô, festô és technológiai robotoknál, hogy a szükséges feladatokat egy megfogóval már nem lehet elvégezni, illetve az illesztési mûveletek végrehajtásához célszerszámok szükségesek. Sokszor olyan bonyolult a szerelési feladat, hogy a probléma univerzális vagy többszerszámos cserélôfejjel sem oldható meg. Ilyen esetekben megoldás lehet a szerelôeszközök automatikus cseréje. Természetesen mindez nem zárja ki, hogy a cserélendô eszközök is lehetnek többfunkciósak, vagyis korlátozottan univerzálisak. Egy másik lényeges szempont, a robotok hatékonyságának a növelése. Sok esetben, amikor egy univerzális robotot alkalmaznak, meg kell teremteni annak a feltételét, hogy a robot gyorsan tudjon alkalmazkodni az adott feladat elvégzéséhez. Ezt meg lehet valósítani szoftveres és mechanikai úton. Szoftveres úton általában pályaoptimalizálással lehet csökkenteni az idôt. Mechanikai úton fôleg a nagy tartományban változó különbözô méretû 
szerszámok vagy munkadarabok megfogása vagy felvétele jelent idôveszteséget. Ezt a problémát úgy lehet kiküszöbölni, hogy egy automata cserélôt alkalmazunk.

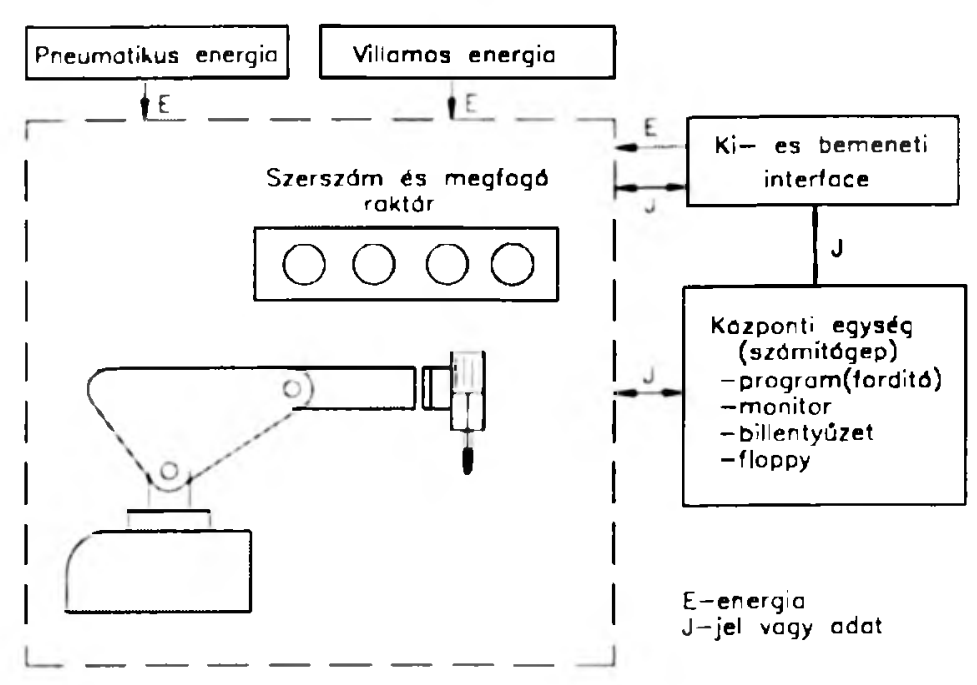

1. ábra

Egy automata szerszám- és megfogócserélô sémája az 1 . ábrán látható. A rendszer energiaellátásához villamos- és pneumatikus energia betáplálása szükséges. A robot és, a cserélôn keresztül, a megfogok meg a szerszámok a központi egységrôl vezérelhetôek. A cserélô minden esetben egy robot-oldali és legalább kettô megfogó-oldali adapterbôl áll (lásd 2. ábra). A megfogó-oldali adapterre erôsítik

fel a megfogókat és a szerszámokat. Az utolsó robotcsuklóra felszerelt robot-oldali adapter ezeket veszi

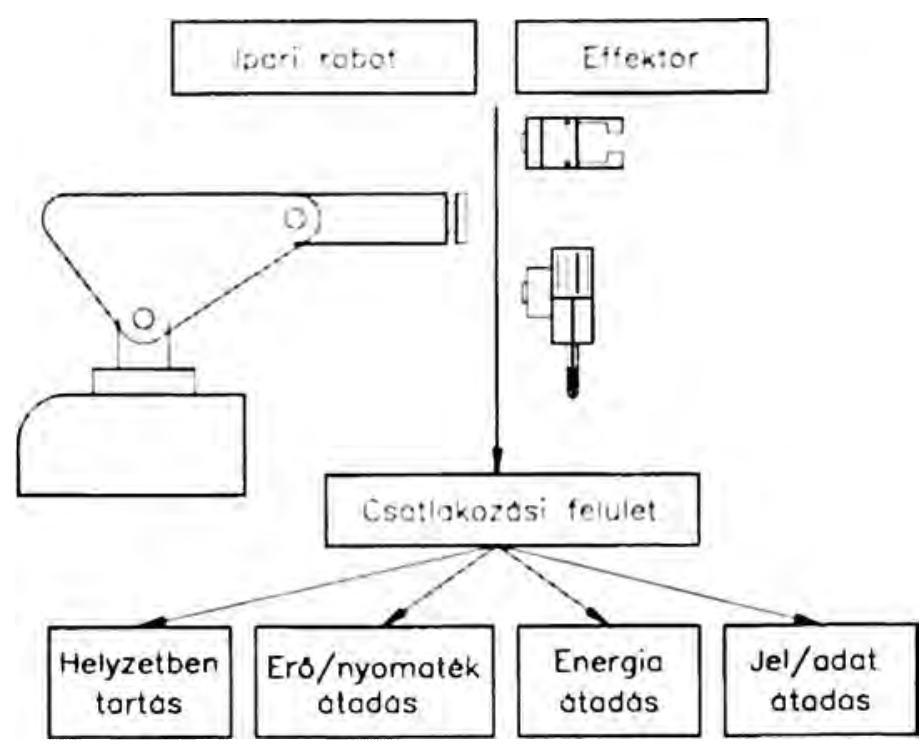
fel kapcsolódáskor. A szerszámok mûködéséhez szük-séges energia átvitele, illetve ha a szerszámban léteznek érzékelôk, az érzékelôk által szolgáltatott jelek továbítása az adapterbe beépített csatlakozókon át történik. A megfogok és a szerszámok nyugalmi hely-zetükben egy erre a célra kialakított tárolóban helyez-kednek el.

2. ábra

\section{Tervezési szempontok:}

-rövid felcsatolási idô az idôveszteségek csökkentésére, -energiakimaradás esetén is megmaradó kapcsolódás (biztonsági okokból), - a csatlakozás legyen merev, tudjon erôt meg nyomatékot közvetíteni, -a csatlakozási felületen lehessen energiát közvetíteni (pl. villamos és pneumatikus), 
-a felcsatolás legyen ellenôrizheto a robotot vezérlô számítógép által, -csak kis mértékben csökkenjen a robot poziciónálási hibája a cserélô használatával, -a cserélô legyen könnyû és kisméretû, hogy ne terhelje feleslegesen a robotot, -könnyen felszerelhetô legyen több tipusú robotra, -ismerje fel a robot a felvett szerszámot vagy megfogót, -a cserélô méretei ne korlátozzák a robotot mozgásában.

Ezen tervezési szempontok alapján, és figyelembevéve az ISO 9409-1 szabvány ajánlásait, a cserélô leg optimálisabb formája a köralakú. A felhasználási szempontokat elemezve azt a következtetést vontam le, hogy 4 pneumatikus- , 9 jel- és 2 elektromos teljesítménycsatorna elegendô minden feladat elvégzéséhez. Igy lehetôség van pneumatikus és elektromos szerszámok és megfogok mûködtetésére. Az elektromos jelátvitel optikai uton történik 9 biten, mert erôssen savas vagy olajos kömyezetben a villamos csatlakozók bizonytalan érintkezést biztosítanak.

\section{A cserélô mûködtetése:}

A cserélô úgy van kialakítva, hogy egyaránt mûködtethetô elektromos vagy pneumatikus úton. Az összecsatolás alakkal való zárás útján történik. A pneumatikus vezérlés egy FESTO gyártmányú miniatür hengerrel (015036 EGZ-10-5) történik 6 bar nyomással. Az elektromágneses vezérlés nem volt kipróbálva, csak a terv készült el. A számítások szerint, mivel elég nagy erôt kell kifejteni, $16 \mathrm{~W}$ hôenergia szabadul fel másodpercenként, a használata nem ajánlott. A mûködtetô egy olyan szpeciális alakú hengeres felületet mozgat, amely alkalmas két radiálisan elhelyezett csapágygolyó kilökésére. Ezek a golyók véghelyzetükben egy ferde falnak ütközve meggátolják a cserélô szétkapcsolódását. Ez a pozició egyébként a golyók nyugalmi helyzete. Fel- meg lecsatoláskor, a hengeres felület elmozdulása lehetôvé teszi, hogy a golyók szabadon visszahúzódjanak a csatomájukba, megengedve a két csatlakozási felület szétválását. A hengeres felület kialakításánál figyelembe volt véve, hogy mozgatásánál a golyóknak ne legyenek nagy sebességugrásai.

\section{Dinamikai rendszeranalizis:}

A dinamikai rendszeranlizishez egy másodrendû modellt alkottam. Feltételeztem, hogy a dugattyú belsejében a nyomás egybôl jelenik meg, a golyók és a fal között nem rugalmas az ütközés. A rendszeregyenlet a következôképpen írható:

$$
m \ddot{x}+b \dot{x}+k x=F(t)
$$

ahol: m - az összes mozgatott tömeg,

b - az eredô surlódási együttható,

$\mathrm{k}$ - a hengerben elhelyezett rugó állandója,

$\mathrm{F}(\mathrm{t})$ - a henger által kifejtett erô,

$\mathrm{x}$ - a dugattyú által megtett út. 
A szimulációt a TUTSIM 7.0 nevû

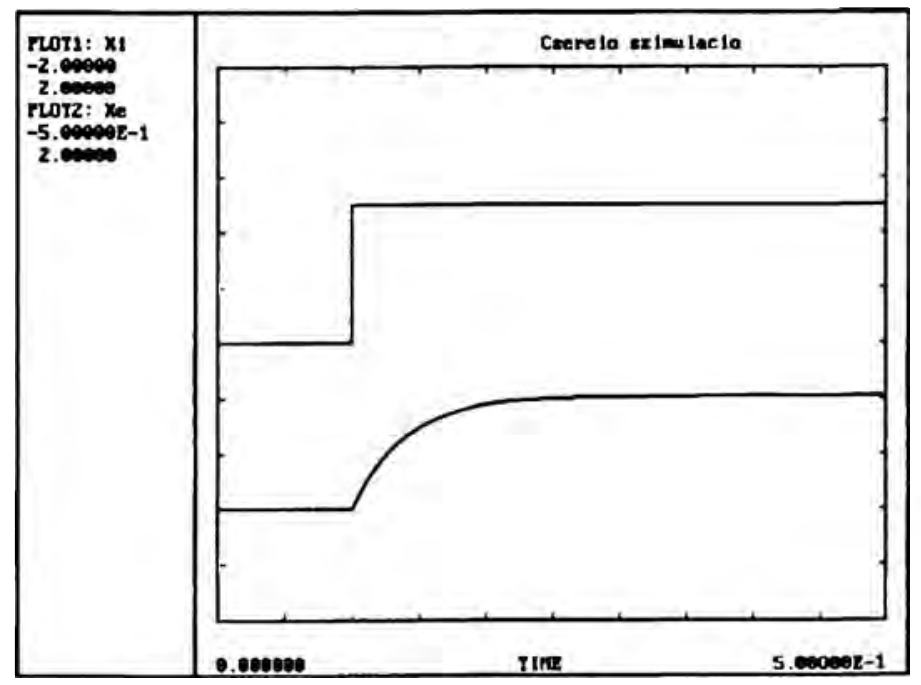

3. ábra

programmal végeztem el és eredménye a 3. ábrán látható. A szimuláció eredményeibôl látható, hogy a rendszernek nagy a csillapítása és elég gyors a mûkôdése. A felcsatolási idôszüksséglet $0.3 \quad \mathrm{~s}$. Ez a valóságban nagyobb, mert figyelembe kell venni a robot poziciónálási idejét, a jelfeldolgozási és a végrehajtási idôket.

A cserélô használatát tovább bövítettem egy 6 komponenses erô- és nyomatékmérôvel, ami lehetôséget adott új mûveletek

elvégzéséhez, mint például:

-az ütközések észlelése manipulálás vagy szerelés közben,

-erô és nyomatékok ellenôrzése munka közben, túlterhelés megakadájozása,

-2D-s pályakôvetés egy tappintó segítségével,

-a megfogó vagy a szerszám pozicionálása a munka megkezdése elôtt.

Egy ilyen automatikus megfogó- és szerszámcserélô egy speciális tároló kialakítását is feltételezi amiben el vannak helyezve a különbözô szerszámok és a megfogok.

\section{Irodalomjegyzék:}

1. Alpek, F.: Greifer- und Werkzeugwechselsysteme Steigerung der Flexibilităt von Montagerobotern, e\&i, vol. 3, Nr. 6/1994, 305-309 oldal.

2. Alpek, F.; Csibi, V.; Gyenge, Cs.; Mihálcz ,I.: Entwicklung und Einsatz der Mechanischen Peripherien von Industrierobotern, DAAAM-95 szimpozium, Krakkó 1995 október 26-28, 9-10 oldal.

3. Mihálcz István: Szerszám- és megfogócserélô valamint flexibilis megfogó tervezése ipari robotokhoz, diplomamunka, Kolozsvári Mûszaki Egyetem 1995.

Mihálcz István okleveles gépészmérnök, doktorandusz hallgató

Budapesti Mûszaki Egyetem, Finommechenikai és Optikai Tanszék, H-1521 Budapest, Pf:91.

Tel:(..36-1) 463-2088, Fax:(..36-1) 463-3787 E-mail: mihalcz@ fot.bme.hu 